\title{
Potential for Energy Savings in Educational Institutions in Ghana
}

\author{
Elvis Twumasi, Emmanuel Asuming Frimpong*, and Leslie Novihoho \\ ${ }^{1}$ Department of Electrical and Electronic Engineering, \\ Kwame Nkrumah University of Science and Technology, Ghana \\ ${ }^{*}$ Corresponding author, e-mail: eafrimpong.soe@knust.edu.gh
}

\begin{abstract}
This paper presents the results of an energy audit carried out to assess the potential of energy savings in educational institutions in Ghana using the Kwame Nkrumah University of Science and Technology (KNUST) as the case study institution. It also outlines a simple and effective technique for such an audit. The College of Engineering; one of the six Colleges of KNUST was used as the study location. Light bulbs and fans at the classrooms, corridors, laboratories and washrooms were monitored for energy wastage. The monitoring period was one month. The energy wastage over the period was estimated to be $1718.24 \mathrm{kWh}$, which is high. The yearly energy wastage at KNUST for the areas assessed is projected to be 95.276MWh, which is alarming. Urgent steps are therefore needed to curb this wastage.
\end{abstract}

Keywords: Energy auditing, Energy efficiency, Energy efficiency measures, Energy saving and Energy wastage

\section{Introduction}

Educational institutions, particularly those at the tertiary level, consume high levels of energy. In Ghana, there is mounting pressure on public higher education institutions, which are wholly funded by the State, to pay their own utility bills due to rising energy cost to government [1]. This presents a challenge to managers of these institutions considering the toll such a policy will have on their finances. The most likely response measure by the managers will be to increase academic facility user fees to take care of the huge cost of energy. This in turn will increase the financial burden on parents with potential agitations from parents and students, which may result in unpleasant outcomes.

Therefore, there is the need to critically assess how energy is utilized in educational institutions with the view to minimize energy cost. Globally, effective energy cost minimization is largely achieved through the active implementation of demand-side management practices that cut down energy wastage. Studies conducted by various researchers point to the fact that the high electricity bills incurred by educational institutions is largely due to gross energy wastage due to inadequate or complete absence of energy management devices, the use of inefficient energy technologies, and lack of energy efficiency awareness [2-7]. For example, the work in [3] reported potential annual energy savings of 33.22MWh with the implementation of energy efficient technologies in an institution in India.
The deployment of energy management schemes in educational institutions largely depends on the top management of the institutions. However, studies conducted in [8] show that top management of various higher education institutions in Ghana pay little or no attention to key practices in the implementation of energy management. This situation may be due to their lack of awareness or appreciation of the enormity of energy wastage in their respective institutions. To such top management, the development of any policy towards energy savings and its consequent implementation must be backed by some level of evidence of energy wastage. Very little has been done by way of demonstrating that significant wastage of energy exists in higher education institutions in Ghana [4]. There is therefore the need to conduct energy audits in the various higher education institutions in Ghana to justify the deployment of energy management schemes by top management.

In the light of this deficiency, this work sought to assess the level of energy wastage at the Kwame Nkrumah University of Science and Technology, the premier science and technology university in Ghana. The study focused on assessing energy wastage due to the inefficient use of light bulbs and fans in classrooms and laboratories as well as light bulbs in corridors and washrooms. The procedure used is simple and effective and can be easily replicated in other institutions. The findings of this work should cause managers of higher education

Received date: 2019-07-23, Revised date: 2019-11-08, Accepted date 2019-11-08

https://doi.org/10.25077/v8n3.661.2019

This work is licensed under a Creative Commons Attribution-ShareAlike 4.0 International License. 
institutions and government to initiate active energy management schemes in the various institutions.

\section{Methodology}

The College of Engineering (COE), which is one of the six Colleges of KNUST, was used as the study location. Light bulbs, fans and all other electrical devices at the College are manually controlled. The manual control of electrical devices brings about high levels of energy wastage due to negligence, apathy and forgetfulness on the part of those expected to switch the devices on and off.

A preliminary assessment pointed to classrooms, corridors, laboratories and washrooms as major areas of energy wastage. The classrooms of the College are found in six buildings namely; Petroleum building (PB), Bamfo-Kwakye building (BB), Kwami building (KB), N-block (NB), Eblock (EB) and Levine Building (LB). There are 19 classrooms in the six buildings. The Petroleum building has the highest number of nine classrooms. The classroom at Levine Building is barely used for lectures and was therefore not monitored for energy wastage. Table 1 shows the classrooms within each building. The laboratories are mainly in the Petroleum building and E-block. Energy wastage assessment was carried out on the use of light bulbs and fans in all the classrooms and laboratories. Lights bulbs at the corridors and washrooms were also monitored for energy wastage. The period of monitoring was one month.

Table 1. Buildings and corresponding classrooms at COE.

\begin{tabular}{|c|c|}
\hline Name of building & Classroom \\
\hline \multirow{9}{*}{ Petroleum Building } & PB001 \\
\hline & PB008 \\
\hline & PB012 \\
\hline & PB014 \\
\hline & PB020 \\
\hline & PB201 \\
\hline & PB208 \\
\hline & PB212 \\
\hline & PB214 \\
\hline \multirow{3}{*}{ Bamfo-Kwakye Building } & RM 206 \\
\hline & RM 303 \\
\hline & RM 304 \\
\hline \multirow{3}{*}{ Kwami Building } & LT \\
\hline & RM A \\
\hline & RM B \\
\hline \multirow[t]{2}{*}{ N-Block } & N1 \\
\hline & $\mathrm{N} 2$ \\
\hline E-block & A110 \\
\hline Levine building & LB \\
\hline
\end{tabular}

Firstly, the total number of lamps and fans to be monitored was determined and their ratings noted. The additional activities carried out to assess the level of energy wastage are outlined below:

a. The lecture timetable was studied to know the times when the classrooms were in use and when not in use. Time allocations in the timetable are done on hourly basis. For periods when the classrooms were not in use, it was found out whether the light bulbs and fans were switched 'off' or left 'on'. Energy wastage was computed based on the number of bulbs and fans that had been left on, their wattages and the 'on' duration.

b. For periods when the classrooms were in use, the study found out whether it was necessary to keep some or all the light bulbs on considering the availability of illumination from the sun. This was done by measuring the level of illumination with and without all the light bulbs 'on' and comparing the measured values with the standard range. Where under or over illumination was identified, the optimal number of light bulbs that should be kept 'on' was determined. The standard level of illumination for classrooms is 300-500 lux [9]. Also, illumination levels exceeding 1100 lux may cause visual discomfort [7].

c. Assessment of energy wastage associated with the inefficient use of light bulbs in the washrooms was done by determining whether the light bulbs should be 'on' or 'off', based on the level of illumination provided by natural light from the sun, and the usage of the washrooms. For example, even though the level of illumination at night calls for artificial lighting, because the washrooms are not in use at night, the light bulbs should be turned on.

d. The light bulbs in the corridors were monitored for energy wastage by determining the number of bulbs that were on when there was adequate illumination from the sun, and the 'on' duration.

e. The usage pattern of the laboratories was also studied. Monitoring of energy use was done by identifying the number of lamps and fans that were 'on' when there was no laboratory activity, and the 'on' duration. 
The amount of energy wasted, $E$, in each of the study areas was computed using (1).

$$
E=N \times P \times t
$$

where $N$ is the number of light bulbs or fans, $P$ is the wattage of light bulbs or fans, and $t$ is the period of wasteful usage.

\section{Results}

Table 1 shows the number and wattage of light bulbs in use at the classrooms, laboratories, corridors and washrooms. The number of fans in working condition at the classrooms and laboratories was also found to be 146 and 20 respectively. The fans in the classrooms and laboratories are each rated $53 \mathrm{~W}$. Table 2 shows the total number and wattage of bulbs and fans in each of the studied classrooms.

Table 1. Number and wattage of light bulbs in use at studied areas

\begin{tabular}{|c|c|c|c|c|}
\hline \multirow{2}{*}{$\begin{array}{c}\text { Wattage of } \\
\text { bulbs(W) }\end{array}$} & $\begin{array}{c}|c| \\
\text { Class } \\
\text { room }\end{array}$ & Laboratory & Corridor & $\begin{array}{c}\text { Wash } \\
\text { Room }\end{array}$ \\
\cline { 2 - 5 } & 0 & 8 & 0 & 0 \\
\hline 15 & 68 & 0 & 0 & 0 \\
\hline 28 & 5 & 0 & 0 & 0 \\
\hline 30 & 223 & 198 & 160 & 58 \\
\hline 36 & 0 & 32 & 0 & 0 \\
\hline 45 & 0 & 0 & 96 & 19 \\
\hline 65 & 36 & 0 & 0 & 0 \\
\hline 75 & 332 & 238 & 256 & 77 \\
\hline Total & & 0 & & 0 \\
\hline
\end{tabular}

Table 2. Number and wattage of bulbs and fans

\begin{tabular}{|c|c|c|c|c|}
\hline \multirow[b]{2}{*}{ Classroom } & \multicolumn{2}{|c|}{ Bulbs } & \multicolumn{2}{|c|}{ Fans } \\
\hline & Total no. & $\begin{array}{c}\text { Wattage } \\
\text { (W) }\end{array}$ & Total no. & $\begin{array}{l}\text { Wattage } \\
\text { (W) }\end{array}$ \\
\hline PB001 & 24 & 36 & 8 & 53 \\
\hline PB008 & 26 & 36 & 6 & 53 \\
\hline PB012 & 18 & 36 & 5 & 53 \\
\hline PB014 & 36 & 36 & 9 & 53 \\
\hline РB020 & 27 & 36 & 8 & 53 \\
\hline PB201 & 24 & 36 & 8 & 53 \\
\hline PB208 & 20 & 36 & 6 & 53 \\
\hline PB212 & 24 & 36 & 12 & 53 \\
\hline PB214 & 24 & 36 & 12 & 53 \\
\hline RM 206 & 5 & 30 & 7 & 75 \\
\hline RM 303 & 24 & 28 & 11 & 75 \\
\hline RM 304 & 16 & 28 & 7 & 75 \\
\hline LT & 12 & 28 & 7 & 75 \\
\hline A110 & 16 & 28 & 13 & 75 \\
\hline N1 & 8 & 75 & 6 & 75 \\
\hline N2 & 12 & 75 & 10 & 75 \\
\hline RM A & 8 & 75 & 6 & 75 \\
\hline RM B & 8 & 75 & 5 & 75 \\
\hline
\end{tabular}

\subsection{Measure illumination values}

Figures 1a and 1b show sample measured average daily illumination (in lux) during peak hours of sunshine at the classrooms in the Petroleum Building. Figures 2 and 3 also show measured illumination levels at the classrooms in the other buildings.

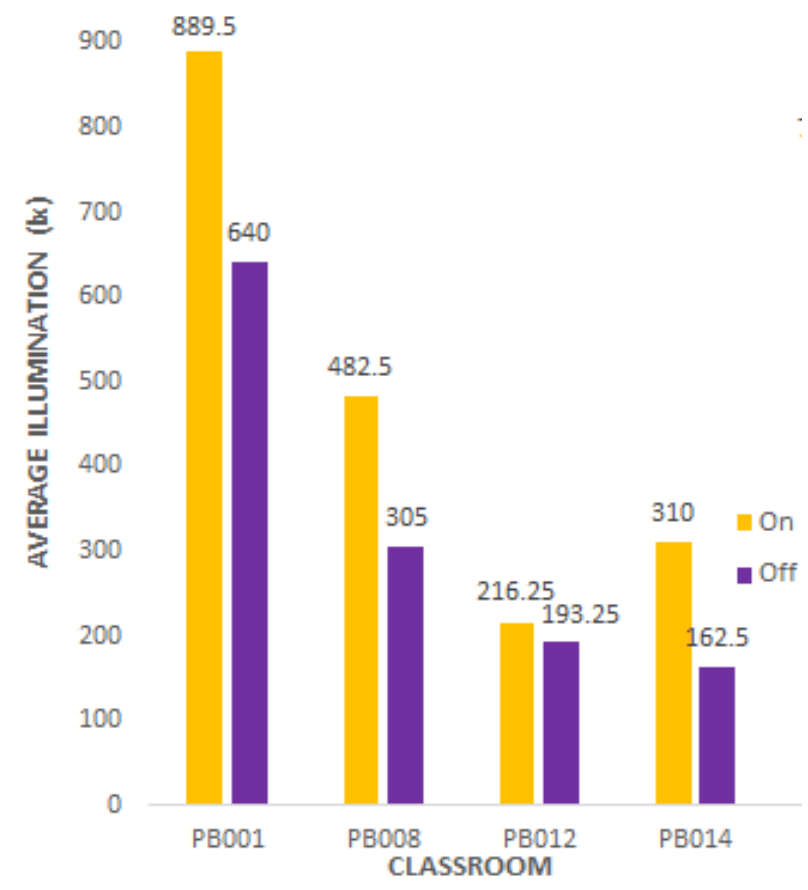

Figure 1a. Measured average illumination at the Petroleum building

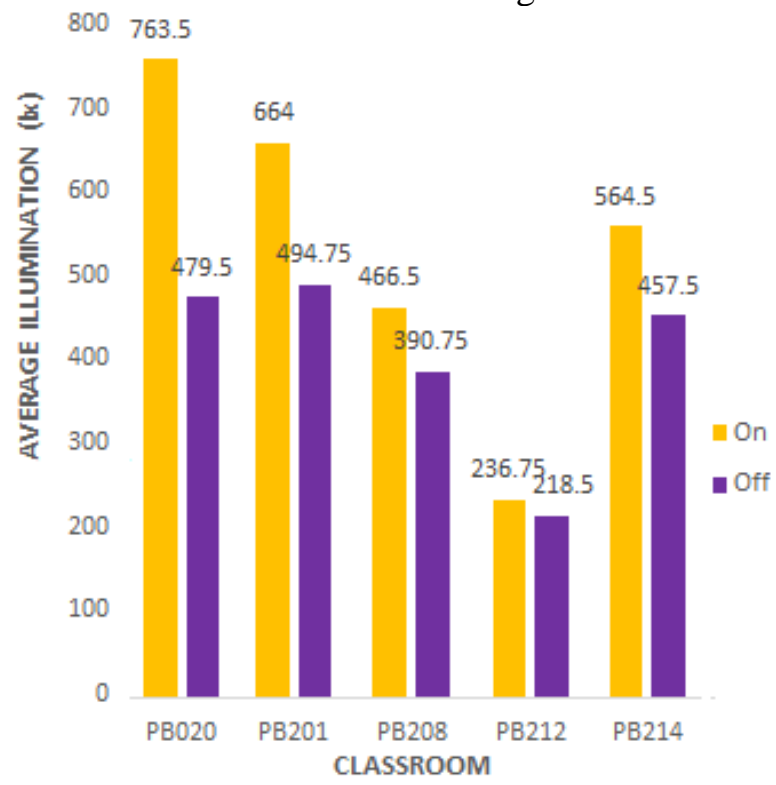

Figure 1b. Measured average illumination at the Petroleum building 


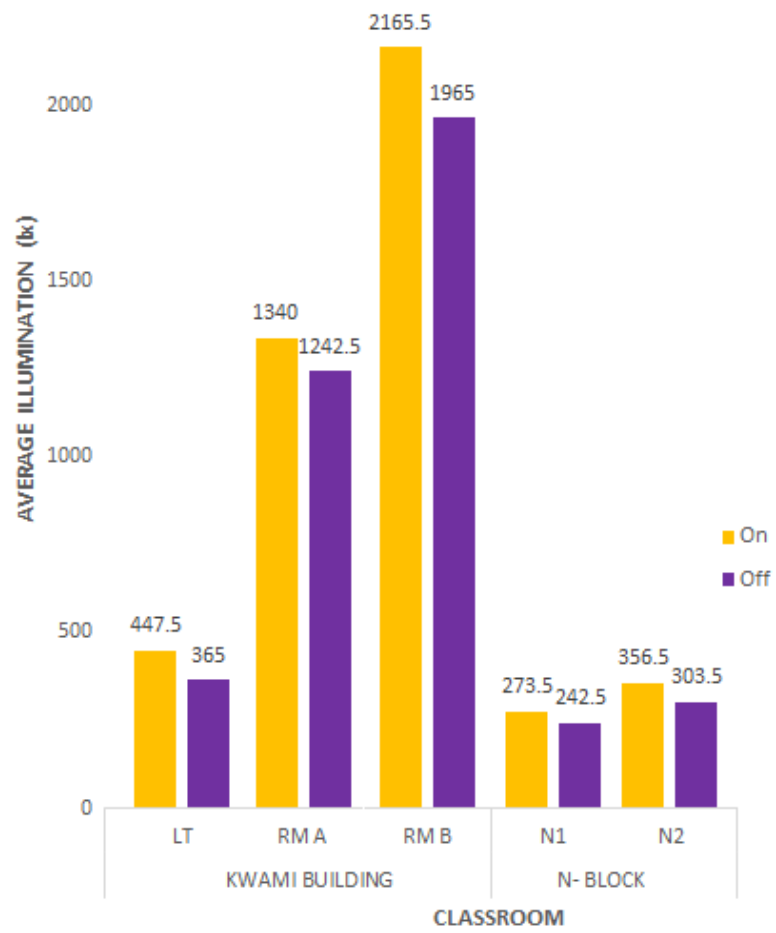

Figure 2. Measured average illumination at KB and NB

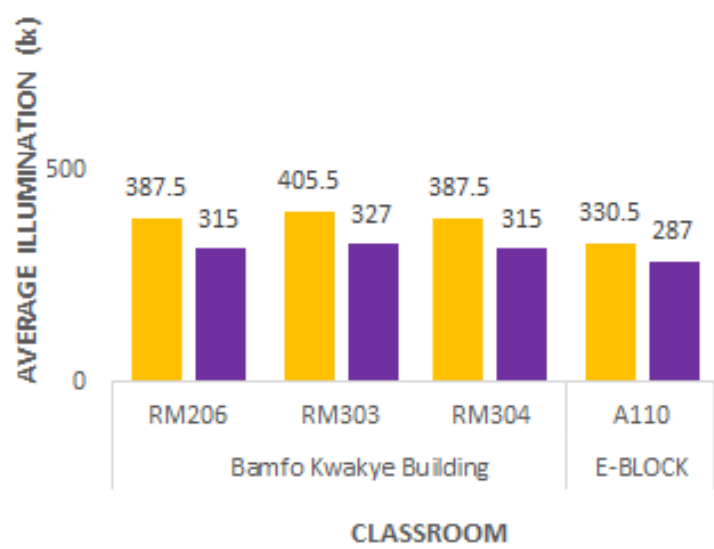

Figure 3. Measured average illumination at BB and EB

It is noted from Figures 1a, 1b, 2 and 3 that the levels of illumination with the light bulbs switched on are higher than when the bulbs are switched off, which is expected. The illumination levels during periods of peak sunshine for some of the classrooms PB001 (figure 1a), PB020, PB201 PB214 (figure 1b), RM A and RM B (figure 2) are found to be very high, even exceeding standard levels. This is so because the windows do not have blinds, as such, all the sunshine is admitted into the rooms. This usually creates discomfort for students.

Again, from the figures, the levels of illumination for most of the classrooms, when the light bulbs are switched off are within the standard range, with some even exceeding the maximum standard value. For example, a very high illumination value of 1965 lux was recorded at RM $B$ in figure 2. This overly high value is due to the orientation of the classroom and the fact that the windows have no blinds. It is therefore evident that keeping the bulbs on during such periods results in energy wastage.

\subsection{Energy wastage due to inefficient usage of light bulbs in classrooms}

Tables 3, 4, 5 and 6 show the hours of energy wastage, the number of bulbs involved, their wattages and calculated wasted energies for weeks $1,2,3$ and 4 respectively. The hours of energy wastage captured in the tables include wasteful hours due to over illumination in the presence of natural light. The wasted energies were calculated using (1).

Table 3. Energy wastage data for week 1

\begin{tabular}{|l|c|c|c|c|}
\hline Classroom & $\begin{array}{c}\text { Hours, t } \\
\text { (hours) }\end{array}$ & $\begin{array}{c}\text { No. of } \\
\text { bulbs, } \\
\text { N }\end{array}$ & $\begin{array}{c}\text { Wattage } \\
\text { of bulbs, } \\
\text { P } \\
\text { (W) }\end{array}$ & $\begin{array}{c}\text { Calculated } \\
\text { Wasted } \\
\text { Energy, E } \\
\text { (Wh) }\end{array}$ \\
\hline PB001 & 11 & 18 & 36 & 7128 \\
\hline PB008 & 17 & 14 & 36 & 8568 \\
\hline PB012 & 14 & 13 & 36 & 6552 \\
\hline PB014 & 12 & 32 & 36 & 13824 \\
\hline PB020 & 14 & 24 & 36 & 12096 \\
\hline PB201 & 12 & 15 & 36 & 6480 \\
\hline PB208 & 12 & 18 & 36 & 7776 \\
\hline PB212 & 14 & 15 & 36 & 7560 \\
\hline PB214 & 13 & 12 & 36 & 5616 \\
\hline RM206 & 11 & 5 & 30 & 1650 \\
\hline RM303 & 14 & 15 & 28 & 5880 \\
\hline RM304 & 12 & 8 & 28 & 2688 \\
\hline LT & 15 & 8 & 28 & 3360 \\
\hline RMA & 19 & 6 & 75 & 8550 \\
\hline RMB & 15 & 2 & 75 & 2250 \\
\hline A110 & 12 & 12 & 28 & 4032 \\
\hline N1 & 13 & 6 & 75 & 5850 \\
\hline N2 & 14 & 6 & 75 & 6300 \\
\hline & & & & 116160 \\
\hline
\end{tabular}


Table 4. Energy wastage data for week 2

\begin{tabular}{|l|c|c|c|c|}
\hline Classroom & $\begin{array}{c}\text { Hours, t } \\
\text { (hours) }\end{array}$ & $\begin{array}{c}\text { No. of } \\
\text { bulbs, } \\
\text { N }\end{array}$ & $\begin{array}{c}\text { Wattage } \\
\text { of bulbs, } \\
\text { P } \\
\text { (W) }\end{array}$ & $\begin{array}{c}\text { Calculated } \\
\text { Wasted } \\
\text { Energy, E } \\
\text { (Wh) }\end{array}$ \\
\hline PB001 & 11 & 20 & 36 & 7920 \\
\hline PB008 & 17 & 18 & 36 & 11016 \\
\hline PB012 & 14 & 16 & 36 & 8064 \\
\hline PB014 & 12 & 34 & 36 & 14688 \\
\hline PB020 & 14 & 24 & 36 & 12096 \\
\hline PB201 & 12 & 20 & 36 & 8640 \\
\hline PB208 & 12 & 19 & 36 & 8208 \\
\hline PB212 & 14 & 16 & 36 & 8064 \\
\hline PB214 & 13 & 16 & 36 & 7488 \\
\hline RM206 & 10 & 4 & 30 & 1200 \\
\hline RM303 & 14 & 24 & 28 & 9408 \\
\hline RM304 & 12 & 6 & 28 & 2016 \\
\hline LT & 18 & 15 & 28 & 7560 \\
\hline RMA & 19 & 6 & 75 & 8550 \\
\hline RMB & 15 & 6 & 75 & 6750 \\
\hline A110 & 12 & 12 & 28 & 4032 \\
\hline N1 & 13 & 6 & 75 & 5850 \\
\hline N2 & 13 & 6 & 75 & 5850 \\
\hline \multicolumn{7}{|c|}{ Total } & & 137400 \\
\hline
\end{tabular}

Table 5. Energy wastage data for week 3

\begin{tabular}{|l|c|c|c|c|}
\hline Classroom & $\begin{array}{c}\text { Hours, t } \\
\text { (hours) }\end{array}$ & $\begin{array}{c}\text { No. of } \\
\text { bulbs, } \\
\text { N }\end{array}$ & $\begin{array}{c}\text { Wattage } \\
\text { of bulbs, } \\
\text { P } \\
(\mathrm{W})\end{array}$ & $\begin{array}{c}\text { Calculated } \\
\text { Wasted } \\
\text { Energy, E } \\
\text { (Wh) }\end{array}$ \\
\hline PB001 & 11 & 21 & 36 & 8316 \\
\hline PB008 & 17 & 17 & 36 & 10404 \\
\hline PB012 & 14 & 16 & 36 & 8064 \\
\hline PB014 & 12 & 30 & 36 & 12960 \\
\hline PB020 & 14 & 24 & 36 & 12096 \\
\hline PB201 & 12 & 22 & 36 & 9504 \\
\hline PB208 & 12 & 17 & 36 & 7344 \\
\hline PB212 & 15 & 18 & 36 & 9720 \\
\hline PB214 & 13 & 21 & 36 & 9828 \\
\hline RM 206 & 11 & 4 & 30 & 1320 \\
\hline RM 303 & 14 & 12 & 28 & 4704 \\
\hline RM 304 & 12 & 4 & 28 & 1344 \\
\hline LT & 17 & 13 & 28 & 6188 \\
\hline RMA & 21 & 6 & 75 & 9450 \\
\hline RMB & 15 & 7 & 75 & 7875 \\
\hline A110 & 12 & 14 & 28 & 4704 \\
\hline N1 & 13 & 8 & 75 & 7800 \\
\hline N2 & 14 & 7 & 75 & 7350 \\
\hline \multicolumn{2}{|r|}{ Total } & & 138971 \\
\hline
\end{tabular}

Table 6. Energy wastage data for week 4

\begin{tabular}{|l|c|c|c|c|}
\hline Classroom & $\begin{array}{c}\text { Hours, t } \\
\text { (hours) }\end{array}$ & $\begin{array}{c}\text { No. } \\
\text { of } \\
\text { bulbs, } \\
\text { N }\end{array}$ & $\begin{array}{c}\text { Wattage } \\
\text { of } \\
\text { bulbs, P } \\
\text { (W) }\end{array}$ & $\begin{array}{c}\text { Calculated } \\
\text { Wasted } \\
\text { Energy, E } \\
\text { (Wh) }\end{array}$ \\
\hline PB001 & 11 & 22 & 36 & 8712 \\
\hline PB008 & 17 & 16 & 36 & 9792 \\
\hline PB012 & 14 & 15 & 36 & 7560 \\
\hline PB014 & 12 & 33 & 36 & 14256 \\
\hline PB20 & 14 & 25 & 36 & 12600 \\
\hline PB201 & 12 & 21 & 36 & 9072 \\
\hline PB208 & 12 & 16 & 36 & 6912 \\
\hline PB212 & 14 & 21 & 36 & 10584 \\
\hline PB214 & 13 & 21 & 36 & 9828 \\
\hline RM206 & 11 & 2 & 30 & 660 \\
\hline RM303 & 14 & 16 & 28 & 6272 \\
\hline RM304 & 12 & 8 & 28 & 2688 \\
\hline LT & 18 & 16 & 28 & 8064 \\
\hline RMA & 19 & 6 & 75 & 8550 \\
\hline RMB & 15 & 5 & 75 & 5625 \\
\hline A110 & 12 & 10 & 28 & 3360 \\
\hline N1 & 13 & 6 & 75 & 5850 \\
\hline N2 & 14 & 8 & 75 & 8400 \\
\hline \multicolumn{7}{|l}{} & & & 138785 \\
\hline
\end{tabular}

The calculated energy wastages associated with the inefficient use of light bulbs in the classrooms at the various buildings over the one-month period are presented as figure 4 . The highest level of energy wastage is noted to occur at the Petroleum building (PB). This is largely due to the high number of classrooms in the building. Zero energy wastage was recorded at the Levine building because it has only one classroom which is hardly used for lectures and the light bulbs turned off as required.

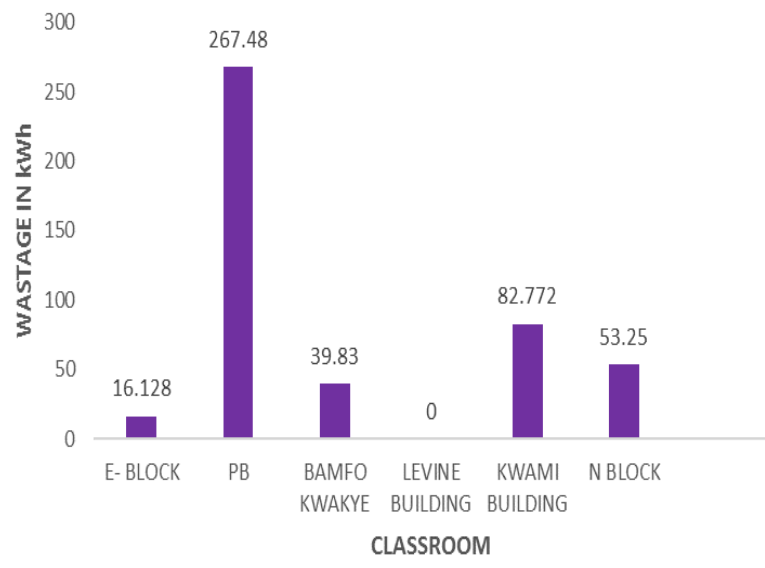

Figure 4. Calculated monthly energy wastage due to wasteful lighting in classrooms. 


\subsection{Energy wastage due to inefficient usage of light bulbs in corridors and washrooms}

Figure 5 and Figure 6 show calculated monthly energy wastages due to wasteful lighting at the corridors and washrooms respectively of the various buildings. These values were calculated in the same manner as shown in Tables 3 to 6 . The high energy wastage at the Petroleum building is due to the large number of washrooms there. There are no washrooms at the N-block.

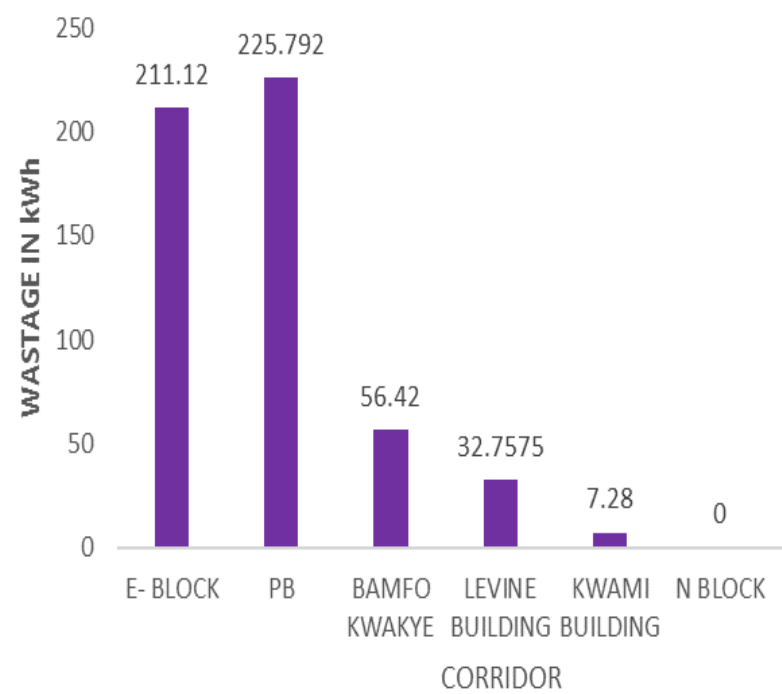

Figure 5. Calculated monthly energy wastage due to wasteful lighting in corridors.

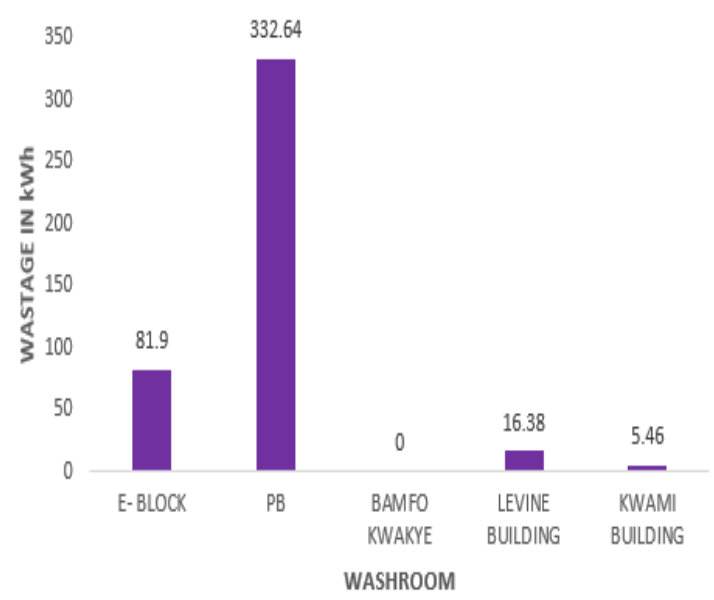

Figure 6. Calculated monthly energy wastage due to wasteful lighting in washrooms

The energy wastage at the laboratories due to the inefficient use of light bulbs was estimated to be $132.48 \mathrm{kWh}$. Here, it was observed that some of the laboratories had their lights bulbs switched 'on' throughout the night. The reason given for this rather inefficient practice is the provision of security against theft. This practice of keeping the light bulbs 'on' throughout the night contributed largely to the energy wastage recorded. A more efficient means of achieving the desired effect will be using occupancy sensing devices.

\subsection{Energy wastage due to inefficient usage of fans}

Figure 7 shows calculated monthly energy wastages due to wasteful use of fans in the classrooms. The highest energy wastage for the monitoring period was recorded at the Petroleum building, followed by the Kwami building. However, since the Kwami Building has three classrooms as against nine classrooms in the Petroleum building, there is greater energy wastage at the Kwami Building. The classrooms at the Kwami Building are also less frequently used compared with the classrooms at the Petroleum Building. Notwithstanding the less frequent usage of the classrooms at the Kwami building, the fans are hardly switched off. The zero-energy wastage recorded at the Levine building is due to the near non-usage of the single classroom there.

The monthly energy wastage at the laboratories due to the inefficient use of fans was calculated to be $63.63 \mathrm{kWh}$

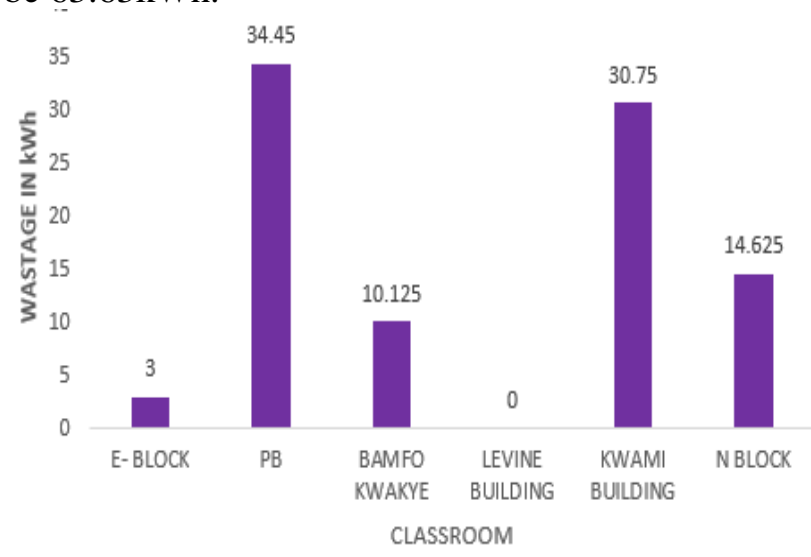

Figure 7. Calculated monthly energy wastage due to wasteful use of fans in classrooms

Table 7 provides a summary of the energy wastage computed at the various buildings and laboratories. The total energy wastage due to the inefficient use of light bulbs and fans at the classrooms, laboratories, washrooms and corridors, for the monitoring period, is $1718.24 \mathrm{kWh}$. At the current electricity cost of $\mathrm{GH} \varnothing 1.265$ per $\mathrm{kWh}$ for this consumption category [10], the monthly wasted 
energy translates into an amount of $\mathrm{GH} \phi 2173.573$, which is high.

Table 7. Computed energy wastages.

\begin{tabular}{|l|c|c|c|c|l|}
\hline Block & $\begin{array}{c}\text { CR } \\
\text { lights } \\
(\mathrm{kWh})\end{array}$ & $\begin{array}{c}\text { CO } \\
\text { lights } \\
(\mathrm{kWh})\end{array}$ & $\begin{array}{c}\text { WR } \\
\text { lights } \\
(\mathrm{kWh})\end{array}$ & $\begin{array}{c}\text { Fans } \\
(\mathrm{kWh})\end{array}$ & $\begin{array}{c}\text { Total } \\
(\mathrm{kWh})\end{array}$ \\
\hline $\mathrm{EB}$ & 16.128 & 211.12 & 81.90 & 3.00 & 312.148 \\
\hline $\mathrm{PB}$ & 267.48 & 225.792 & 332.64 & 34.45 & 860.362 \\
\hline $\mathrm{BB}$ & 39.83 & 56.420 & 0 & 10.125 & 106.375 \\
\hline LB & 0 & 32.7575 & 16.38 & 0 & 49.1375 \\
\hline $\mathrm{KB}$ & 82.772 & 7.280 & 5.46 & 30.75 & 126.262 \\
\hline $\mathrm{NB}$ & 53.25 & 0 & 0 & 14.625 & 67.875 \\
\hline LAB & 132.48 & 0 & 0 & 63.6 & 196.08 \\
\hline Total & 591.94 & 533.3695 & 436.38 & 156.55 & $\mathbf{1 7 1 8 . 2 4}$ \\
\hline
\end{tabular}

Using the energy wastage data presented in Table 7 , the annual energy wastage is calculated to be $15879.39 \mathrm{kWh}$ using 8 months of usage of classrooms, 8 months of usage of washrooms, 8 months of active usage of laboratories and 12 months of corridor lighting. This translates into a yearly wasted amount of $\mathrm{GH} \phi 20087.43$. Since KNUST has six colleges with similar energy use, the projected energy wastage for KNUST in the areas studied could be in the neighbourhood of $6 \times 15879.39 \mathrm{kWh}=95,276.34 \mathrm{kWh}$.

\section{Conclusion}

The results of a study to determine the potential for energy saving in educational institutions in Ghana using KNUST as the case study institution has been presented. The study considered energy saving potential in the use of light bulbs and fans at classrooms, laboratories, corridors and washrooms. It was realized that $15879.39 \mathrm{kWh}$ of energy is wasted yearly at one of the colleges of the University in the aforementioned areas alone. There is therefore the potential to save huge amounts of energy in KNUST and by extension, educational institutions in Ghana. Broadening the scope of the audit in the current institution to cover air conditioners in addition to further energy audits in all institutions of learning in the country will provide an enhanced appreciation of the enormity of energy wastage in educational institutions in the country. This will strengthen the need for widescale deployment of energy management devices.

\section{Acknowledgement}

The authors are grateful to the KNUST Research Fund (KReF) for providing financial support for the study.

\section{References}

[1] Tertiary students to pay utility bills as government shares cost, Retrieved from http://www.myjoyonline.com/news/2015/Ap ril-22nd/tertiary-students-to-pay-utilitybills-as-government-shares-costs.php .

[2] A. K. Aliyu, A. L. Bukar, J. G. Ringim, and A. Musa, "An Approach to Energy Saving and Cost of Energy Reduction Using an Improved Efficient Technology", Open Journal of Energy Efficiency, vol. 4, pp. 6168, 2015.

[3] S. R. Kalbande, V. P. Khambalkar and D. Sneha, "Energy conservation of educational institution: A case-study", International Journal of Research in Engineering, Science and Technologies, vol. 1, no. 5, pp. 12-16, 2016.

[4] K. E. Adjei-Saforo, M. Adam, K. NtiamoahSarpong, E. O. K. Addo and H. Su, "A Research on Electrical Energy Audit in an Educational Institution-A Case Study", International Journal of Research in Engineering and Technology, vol. 5, no. 7, pp. 229-234, 2017.

[5] M. H. Ishak et al, "Estimating potential saving with energy consumption behaviour model in higher education institutions", Sustainable Environment Research, vol. 26, pp. 268-273, 2016.

[6] A. Roslizar, M. A. Alghoul, B. Bakhtyar, N. Asim, and K. Sopian, "Annual Energy Usage Reduction and Cost Savings of a School: End-Use Energy Analysis", The Scientific World Journal, vol. 2014, pp. 1-8, 2014.

[7] R. Aiman, M. A. Alghoul, B. Bakhtyar, Asim N. and K. Sopian, "Annual Energy Usage Reduction and Cost Savings of a School: End-Use Energy Analysis", The Scientific World Journal, pp. 1-8, 2014.

[8] M. Sapri, A. Adjei-Twum, S. T. Low, D. Amos and Z. A. Muin, "Energy Management in Public Higher Education Institutions in Ghana", Journal of Resources Development and Management, vol. 16, pp. 32-41, 2016. 
[9] Charted Institute of Building Services Engineers, "Energy Efficiency in Buildings, CIBSE Guide F", 2004.

[10] Public Utility Regulatory Commission, Publication of Electricity Tariffs (2019). Retrieved from http://www.purc.com.gh/purc/sites/default/fi les/purc_approved_2019-

2020_electricity_tariffs.pdf 